\title{
Hormonally Induced Spawning, Embryonic Development and Larval Rearing of the Southern Temperate Banded Morwong Cheilodactylus spectabilis
}

\author{
Arthur J. Ritar ${ }^{1 *}$, Tyas A. Pribadi ${ }^{2}$ \\ ${ }^{1}$ Marine Research Laboratories, Tasmanian Aquaculture and Fisheries Institute, \\ University of Tasmania, Nubeena Crescent, Taroona, Tasmania 7053, Australia \\ ${ }^{2}$ Department of Zoology, University of Tasmania, Hobart, Tasmania 7001, Australia \\ *Corresponding author: Arthur.Ritar@utas.edu.au
}

\begin{abstract}
Banded morwong (Cheilodactylus spectabilis) are of interest for marine finfish aquaculture in temperate southern Australia. To improve their ovulatory response, adult females were implanted during the autumn spawning season with slow-release pellets containing 0-400 $\mu \mathrm{g}$ luteinizing hormone releasing hormone analogue (LHRHa) $/ \mathrm{kg}$ body weight within $24 \mathrm{~h}$ of capture from the wild. Compared to the sham control group, animals treated with LHRHa produced significantly more eggs on each day after implantation for the following 7 days $(91 \pm 39 \mathrm{ml}$ and $290 \pm 38 \mathrm{ml})$ and a higher proportion ovulated $(8 / 12$ and 27/27). Of fish treated with LHRHa, 93\% ovulated two days after implantation and 79\% ovulated three times at two-day intervals, whereas control animals showed no cyclicity of ovulation and few ovulated more than once. Egg production was highest at the first ovulation after LHRHa treatment and declined at subsequent ovulations. In a second experiment investigating the range 100-400 $\mu \mathrm{g}$ LHRHa, there was no effect of dose rate on ovulation parameters which additionally examined implantation either immediately after capture or after a 5-day delay. Compared to immediate implantation, a delay resulted in a lower proportion of animals which could be stripped after implantation (100\% and 50\%, respectively) and the volume of eggs was lower $(135 \pm 15 \mathrm{ml}$ and $107 \pm 10 \mathrm{ml})$. The egg quality was poor following delayed implantation, resulting in no fertilisation after artificial insemination compared with immediate implantation in which fertilisation and hatch rates were higher for eggs collected on Day 2 after implantation ( $79 \pm 8 \%$ and $58 \pm 9 \%)$ than on Day $4(23 \pm 7 \%$ and $15 \pm 6 \%)$. Thus, it is important to implant animals as soon as possible after capture to ensure optimum egg quality. Good quality eggs were buoyant, spherical and had a diameter of $1050 \pm 25 \mu \mathrm{m}$ with a single pigmented oil droplet of $190 \pm 9 \mu \mathrm{m}$. When a separate large batch of eggs collected two days after implantation with $100 \mu \mathrm{g}$ LHRHa was inseminated and cultured at $18 \mathrm{C}$, larvae hatched after $63 \pm 2 \mathrm{~h}$ at a standard length of $2.6 \pm 0.4 \mathrm{~mm}$. Newly-hatched larvae were buoyant and transparent with only a few melanophores, eyes were non-pigmented and jaws were non-funtional. By the fourth day, jaws were functional and eyes were fully pigmented. Utilisation of the endogenous yolk and oil was completed by Day 6 and swimming commenced with exogenous feeding. Larvae, initially fed lipid-enriched rotifers followed by Artemia, reached $8.9 \pm 0.7 \mathrm{~mm}$ length on Day 55, after which they metamorphosed to the postlarval paperfish stage of development, $22 \pm 0.9 \mathrm{~mm}$ on Day 100, and $43 \pm 1.0 \mathrm{~mm}$ at six months old. The results show that treatment of wild-caught females with slow-release pellets containing LHRHa is effective for the production of eggs for hatchery rearing.
\end{abstract}




\section{Introduction}

For Australia to diversify the aquaculture production of finfish, it must rely on its native temperate and tropical species. This is because strict national quarantine and environmental policies and regulations prevent the importation of exotic species. Banded morwong (Cheilodactylus spectabilis Hutton, 1872), a highly regarded food fish, is found naturally along the coasts of cool temperate southern Australia and New Zealand. It is fully exploited in Australia where there is little scope for further expansion of the wild fishery, which now has strict management plans to maintain a sustainable catch (Ziegler et al. 2005). In New Zealand, the species is protected and there is no legal fishery.

The vast majority of captured fish are destined for the live trade to specialised food markets within Australia (Murphy and Lyle 1999). However, there appears to be considerable opportunity and interest to increase supply through aquaculture to both the domestic and international markets, especially in Asia. This is due to the high market acceptability of its favourable red appearance and eating qualities, and it transports well over long distances (Searle and Zacharin 1994). Although C. spectabilis is long-lived and relatively slow growing as an adult, animals reach sexual maturity at $25-30 \mathrm{~cm}$ (up to $800 \mathrm{~g}$ ) at 2-3 years old (Jordan 1994), a size and growth rate attractive for commercial aquaculture.

Banded morwong is a demersal perciform inhabiting shallow in-shore rocky reefs with larger individuals mostly found at depths to $50 \mathrm{~m}$ (Leum and Choat 1980). Adult males dominate the deeper regions while females and juveniles are found in shallower water. Adults generally do not exceed $3.5 \mathrm{~kg}$, although there are reports that they may reach $15 \mathrm{~kg}$ (Last et al. 1983; Kuiter 1993). Banded morwong have a short autumn spawning season lasting from February to April (McCormick 1989). They are closely related to striped trumpeter (Latris lineata), being sister taxa (Cheilodactylidae and Latridae) with both species having distinctive extended post-larval pelagic "paperfish" stages, where their bodies are deep but laterally compressed, before transition to the juvenile form (Bruce 1989, 1998; Roberts 1995). Juveniles of banded morwong appear in shallow water on rocky reefs and tide pools between September and December (i.e. 5-7 months old) at sizes between 50-79 mm total length (Wolf 1998). As with striped trumpeter, they have pelagic larvae that hatch at a small size and early stage of development, are possibly neustonic, appearing to be transient physostomes as larvae while euphysoclist as adults (Trotter et al. 2004). Unlike striped trumpeter, where considerable research has been undertaken on their aquaculture potential, banded morwong have not, until now, received such attention.

Controlled breeding in captivity is an integral component of finfish aquaculture involving the production of juveniles throughout the year, which depends on the reliable supply of good quality eggs from broodstock. Luteinising hormone releasing hormone analogue (LHRHa) effectively induces ovulation in many teleosts (Zohar 1986; Crim et al. 1987) and has been used extensively in aquaculture. Our earlier unpublished investigations indicated that oocyte development in wild-caught banded morwong females does not progress to ovulation unless they are hormonally induced and that treatment with slow-release cholesterol pellets containing LHRHa, prepared according to the method of Lee et al. (1986), appeared to be an effective method of stimulating ovulation.

This study presents the findings on the successful induction and synchronization of ovulation of wild-caught banded morwong females administered LHRHa pellet implants. Eggs 
produced after hormonal induction were inseminated and cultured through embryonic development to hatch and then to the post-larval paperfish stage.

\section{Materials and Methods}

\section{Capture and Care of Experimental Fish}

Adult fish (0.8-2.2 kg) were caught during the natural spawning season (March-April) by gill-netting close inshore to $10 \mathrm{~m}$ depth in the rocky reef waters off Tasman Peninsula, southern Tasmanian $\left(43^{\circ} 08^{\prime} \mathrm{S}, 148^{\circ} 00^{\prime} \mathrm{E}\right)$ before transfer to 4,000 L tanks at the Marine Research Laboratories, Taroona. Only fish in good condition with few or no obvious skin or eye lesions were included in two experiments and received a plastic numbered tag in the dorsal musculature, and weight, length, and body condition were recorded. Animals were held in tanks at a density of up to $10 \mathrm{~kg} / \mathrm{m}^{3}$ and supplied with sea water (34\%o) pumped directly from the River Derwent at a flow rate of approximately $25 \mathrm{~L} / \mathrm{min}$ with a dissolved oxygen concentration of at least $6 \mathrm{mg} / \mathrm{L}$. The water temperature ranged between 14-15 C and fish were exposed to a simulated natural photoperiod.

The selection of sexually mature females for the experiments was based on the ability to express ovulated eggs or on a swelling of the abdomen indicating that the gonads were enlarged. Males were distinctly different in body shape (no abdominal enlargement) and semen could be expressed when the abdomen was squeezed. Females were ranked on increasing body weight and randomly allocated to treatments.

\section{Induction of Ovulation, Insemination and Incubation of Eggs}

Fish were anaesthetised in a water bath containing 0.02\% 2-phenoxyethanol (Sigma Chemical Company, St. Louis, USA) before further handling. Females were administered implants into the dorsal muscle to a depth of approximately $2 \mathrm{~cm}$ at a rate of $0-400 \mu \mathrm{g}$ LHRHa/kg body weight. Implants were prepared by hand with LHRHa (des-Gly 10 [D-Ala 6 ]LH-RH Ethylamide, Sigma) in a matrix of 95\% cholesterol (Sigma) and 5\% coconut oil (Copha) as described by Lee et al. (1986). Females were examined daily for ovulation by gentle pressure applied to the abdomen.

After drying the genital area of males, semen was collected into $10 \mathrm{ml}$ syringes (avoiding contamination with urine, water and mucus) and up to $15 \mathrm{ml}$ could be collected per male but mostly only small volumes $(0.5-2.0 \mathrm{ml})$ could be expressed. The undiluted semen $(5$ x $10^{9} \mathrm{sperm} / \mathrm{ml}$ ) was transferred to covered $70 \mathrm{ml}$ plastic containers held on ice until assessment for motility. For motility assessment at a magnification of 400 times, a small drop of semen adhering to the tip of an $18 \mathrm{G}$ needle was spread thinly on a microscope slide to which was added a drop of filtered sea water (dilution rate of at least 1:5) for sperm activation. Semen samples with a motility rate of at least $80 \%$ were pooled for insemination.

Eggs were inseminated and incubated until hatch during which the fertilisation rate, the proportion of eggs with single or multiple oil droplets and the rate of hatch of larvae were determined. To assess these parameters, aliquots of eggs $(200 \mu$ containing 200 eggs $)$ in $70 \mathrm{ml}$ plastic vials were inseminated with a single drop $\left(50 \mu \mathrm{l}\right.$ containing $200 \times 10^{6}$ motile sperm or 1 x $10^{6}$ motile sperm/egg) of freshly-collected semen pooled from three males. To this was added $60 \mathrm{ml}$ of $0.2 \mu \mathrm{m}$ filtered sea water to activate sperm before transfer to a waterbath at 17 C. The inseminated eggs were rinsed with clean, filtered, temperature-equilibrated sea water within $1 \mathrm{~h}$ and then twice daily until hatch. Water exchange consisted of siphoning from the 
base of the vial and replacement with an equal volume. The effluent water was transferred to separate vials to count the number of opaque sinking (unfertilised and dead) eggs and larvae. The fertilisation rate of the floating eggs was assessed at the 4-8 cell division stage (i.e. within $3 \mathrm{~h}$ after insemination) in a sample of 150 floating eggs. The hatching percentage was determined by calculating the number of larvae hatched as a proportion of the eggs inseminated (included all dead eggs and embryos).

\section{Experiment 1: LHRHa dose}

Within $24 \mathrm{~h}$ of capture and arrival at MRL, 39 running ripe females were treated with pellets: 12, 12, 11 and 4 fish with 0, 100, 200 and $400 \mu \mathrm{g}$ LHRHa/kg body weight, respectively. Animals were stripped daily and the volumes of eggs recorded.

\section{Experiment 2: time of implantation and LHRHa dose}

This 2 × 3 factorial experiment using 40 running ripe females examined implantation with 100,200 or $400 \mu \mathrm{g}$ LHRHa/kg body weight either immediately on arrival at MRL and within $24 \mathrm{~h}$ of capture compared to delayed implantation for 5 days. Animals were examined daily but only stripped either on Days 2 and 4 (when implanted immediately) or Days 2 and 3 (when implantation delayed). Eggs from each ovulating female were inseminated with pooled semen, rinsed in clean water and incubated at $17 \mathrm{C}$ until hatch as described above.

\section{Embryonic and larval development to the post-larval stage}

Eggs $(100 \mathrm{ml})$ from one female treated with $100 \mu \mathrm{g}$ LHRHa/kg body weight were inseminated with $2 \mathrm{ml}$ of pooled semen from three males. Following insemination, eggs were rinsed in clean sea water and transferred to a 400 L black cylindro-conical fibreglass tank (density of 300 eggs/L) in an upwelling, flow-through system with water exchanged at a rate of $25 \% / \mathrm{h}$ through a $63 \mu \mathrm{m}$ screen. As cleavage proceeded, viable eggs remained buoyant while non-viable eggs precipitated and were flushed from tanks 3-4 times daily. At $48 \mathrm{~h}$ and shortly before larval hatch, embryos were stocked at 50 embryos/L into 1,000 L cylindrical black tanks with conical white bases in a semi-open system, where clear, upwelling water was replaced at a rate of $10 \% / \mathrm{h}$ initially, rising to $25 \% / \mathrm{h}$ on Day 12 after hatch. Hatching occurred at 2.6 days post-insemination. Surface skimmers were used to remove proteinaceous films to promote initial swim bladder inflation (Trotter et al. 2004). Triplicate samples were assessed for fertilisation, embryonic and larval development.

Temperature was maintained at $18 \mathrm{C}$ throughout egg incubation and larviculture and the salinity remained at 34\%o. Light was excluded from incubation tanks until Day 4, at which time a photoperiod (16L:8D) was introduced with a maximum light intensity at the water surface of $4 \mu \mathrm{mol} / \mathrm{s} / \mathrm{m}$ (300 lux). $\mathrm{pH}$ was 8.1 and dissolved oxygen was $>85 \%$ saturation.

Rotifers (Brachionus plicatilis) enriched with DHA Selco (INVE Aquaculture) were presented to larvae twice daily at a density of $10 / \mathrm{ml}$ from Day 5 reducing to $5 / \mathrm{ml}$ on Day 12 and maintained at this level until Day 26. Artemia (AF grade, INVE Aquaculture) nauplii were fed twice daily to larvae on Days 16-24 at densities of $0.5 / \mathrm{ml}$, while Artemia (EG grade, INVE Aquaculture) metanauplii enriched with Super Selco and juveniles were fed from Day 24 at a similar rate. A micro-particulate diet (Kyowa, Fukui \& Co., Japan) was introduced on Day 28. 
Analyses of variance (ANOVA; Steel and Torrie 1960) were performed on data after arcsin transformation and critical differences between means (significant at $\mathrm{P}<0.05$, unless stated otherwise) were determined by Fisher's PLSD. The results are presented as untransformed means with associated standard errors.

\section{Results}

\section{Experiment 1: LHRHa dose}

Shortly before implantation on Day 0, 12/27 (44\%) fish receiving LHRHa and 5/12 (42\%) fish receiving no LHRHa could be stripped and the volumes of eggs were not significantly different $(24 \pm 11 \mathrm{ml}$ and $37 \pm 11 \mathrm{ml} ; \mathrm{P}>0.05)$.

Following implantation and for the following 7 days, the proportion of fish which could be stripped (ovulated) was $67 \%, 100 \%, 100 \%$ and $100 \%$ for females treated with implants containing 0, 100, 200 and $400 \mu \mathrm{g}$ LHRHa/kg body weight, respectively (Fig. 1). All except one ovulating fish treated with LHRHa first ovulated by Day 2 after implantation while animals receiving no LHRHa first ovulated randomly throughout the 7 day experiment.

From Day 2 onwards, the proportion of females which could be stripped daily was higher after treatment with LHRHa (pooled for animals receiving 100, 200 and $400 \mu \mathrm{g} / \mathrm{kg}$ ) than for animals receiving no LHRHa (Fig. 2). On Day 2, 100\% of females in the 100 and 400 $\mu \mathrm{g}$ LHRHa treatments and $92 \%$ in the $200 \mu \mathrm{g}$ LHRHa treatment could be stripped while all females receiving LHRHa could be stripped on Day 4 and 69-79\% could be stripped on Day 67. Egg production between Days 1-7 for females receiving no LHRHa was significantly lower than for animals receiving LHRHa but there were no significant differences between doses of LHRHa (Fig. 3). Animals receiving LHRHa exhibited peaks in egg production on Days 2, 4 and 6, although the last elevation on Day 6 was much reduced and not significantly different to egg production on Days 5 or 7. For females receiving no LHRHa, there appeared to be no cyclicity betweeen days of egg stripping. The volume of eggs collected until Day 7 from ovulating fish receiving LHRHa was significantly higher than for no LHRHa (290 $\pm 38 \mathrm{ml}$ and $91 \pm 39 \mathrm{ml}$, respectively). Although total egg production per ovulating female was highest for the $400 \mu \mathrm{g}$ LHRHa treatment $(385 \pm 134 \mathrm{ml})$, it was not significantly different to the 100 and $200 \mu \mathrm{g}$ treatments $(323 \pm 45 \mathrm{ml}$ and $225 \pm 63 \mathrm{ml})$.

\section{Experiment 2: time of implantation and LHRHa dose}

For females implanted immediately on arrival (and within $24 \mathrm{~h}$ of capture), eggs could be collected from $80 \%$ on Day 2 and $100 \%$ on Day 4 , while for females where implantation was delayed for 5 days, only $50 \%$ could be stripped on Day 2 after implantation and an additional $30 \%$ could be stripped on Day 3 and none could be stripped thereafter. The volume of eggs produced per ovulating female up to Day 4 was significantly lower when implantation was delayed compared to immediate implanation $(107 \pm 10 \mathrm{ml}$ and $135 \pm 15 \mathrm{ml})$ but was not significantly different between LHRHa doses (Fig. 4).

Females that had implantation delayed for 5 days and were collected on Days 2 and 3 after treatment invariably had poor, watery eggs with no fertilisation and were discarded from further study. The eggs from females implanted immediately on arrival were visually assessed as high quality on Days 2 and 4 after implantation, with a diameter of $1050 \pm 25 \mu \mathrm{m}$ (range 950-1100 $\mu \mathrm{m}$ ) and mostly containing a single pigmented oil droplet of $190 \pm 9 \mu \mathrm{m}$ diameter. However, fertilisation rate was significantly lower after insemination on Day 4 than on Day 2 
$(23 \pm 7 \%$ and $79 \pm 8 \%$, Table 1$)$. This was followed by significantly higher embryonic mortality on the first day of incubation for eggs collected on Day 4 than Day $2(51 \pm 7 \%$ and 2 $\pm 1 \%$ ), consequently resulting in lower larval hatch $(15 \pm 6 \%$ and $58 \pm 9 \%)$.

\section{Embryonic and larval development to the post-larval stage}

Fertilisation could be determined at the two-cell stage within $2 \mathrm{~h}$ after insemination and was $80 \pm 3 \%$. Embryos were buoyant, clear and spherical. The duration to hatch at $18 \mathrm{C}$ was 63 (47.5 degree-days) $\pm 2 \mathrm{~h}$ and the hatch rate was $70 \pm 5 \%$. Newly-hatched larvae were transparent apart from a few melanophores, the eyes were non-pigmented and the jaws were non-functional. The oil droplet was located toward the front of the yolk sac. The primordial finfold surrounded the trunk in the median position. By the fourth day after hatch, larval jaws were functional and eyes were fully pigmented. Utilisation of endogenous yolk and oil was completed by Day 6 and swimming commenced with exogenous feeding. Swim bladder inflation, which occurred by Day 11, was associated with behavioural changes. Up to this time, larvae were generally distributed evenly throughout the tank while afterwards, larvae congregated near the tank walls and near the surface.

At hatch, larvae were buoyant and had a standard length of $2.6 \pm 0.2 \mathrm{~mm}$, increasing to $3.2 \pm 0.2 \mathrm{~mm}$ at $48 \mathrm{~h}$ with daily measures taken to Day $20(4.9 \pm 0.4 \mathrm{~mm})$ (Fig. 5). Growth continued at a similar rate until the next measurement on Day $55(8.9 \pm 0.7 \mathrm{~mm})$, approximately at notochord flexion, but then accelerated to Day 100 when animals reached 22 $\pm 1.8 \mathrm{~mm}$ after metamorphosis to the post-larval paperfish stage. The post-larvae survived to six months old at a total length of $43.0 \pm 1.0 \mathrm{~mm}$ and weight of $0.8 \pm 0.1 \mathrm{~g}$.

\section{Discussion}

Analogues of LHRH have been used for the induction of ovulation in many commercially important finfish (reviewed by Mylonas and Zohar 2001). This study found that treatment with slow-release LHRHa implants was beneficial for the induction and synchronization of ovulation in wild-caught banded morwong. LHRHa implants at doses between $100-400 \mu \mathrm{g} / \mathrm{kg}$ body weight were equally effective in stimulating ovulation in a high proportion of females, whereas implants containing no LHRHa produced fewer ovulating females and in which there appeared no pattern of synchrony. There was no advantage in using doses higher than $100 \mu \mathrm{g} / \mathrm{kg}$, although lower doses may be effective but were not examined. Similarly in the closely related striped trumpeter (Latris lineata), the LHRHa dose regime of pellets administered at $100 \mu \mathrm{g} / \mathrm{kg}$ also maximized the ovulatory response in sexually mature females during the peak spawning season (Morehead et al. 1998).

Of the females in the first experiment which were treated with LHRHa, >97\% ovulated and could be stripped two days after implantation, producing on average $>100 \mathrm{ml}$, equating to more than 200,000 eggs/fish. After another two days, all these animals spawned again, although egg production declined to $<80 \mathrm{ml}$. A similar pattern was seen in the second experiment as well as in our subsequent studies. Therefore, the treatment may be recommended for the reliable induction of ovulation during the spawning season at least for the first two ovulations after treatment. The results also suggest that banded morwong are naturally multiple spawners and that ovarian development is "multiple group-synchronous" (Pankhurst 1998). This is similar to striped trumpeter in which there are a number of oocyte populations present in the ovary at one time and recruitment to maturing and hydrated oocytes 
occurs from at least the cortical alveoli stage of development (Morehead et al. 1998). However, unlike striped trumpeter, banded morwong appear to have species specific inhibitions or stresses including non-feeding of recently captured animals. Thus, regular ovulations did not continue beyond the first 2-3 ovulations following implantation. It is possible that in most animals treated with sham pellets, there was arrested development of maturing oocytes. Ovarian atresia soon after the stresses of capture, handling and confinement commonly occurs in other species (Woods and Sullivan 1993; Clearwater and Pankhurst 1997; Pankhurst 1998) but the cause is not well understood. Also unlike striped trumpeter, where final oocyte maturation takes $80 \mathrm{~h}$ at $11 \mathrm{C}$, it only takes $48 \mathrm{~h}$ in banded morwong at 14-15 C.

Although the egg production at the second ovulation on Day 4 after implantation was only reduced by $\sim 20 \%$ compared to the first ovulation, the fertilisation and larval hatch rates were reduced markedly, possibly reflecting the stresses suffered by these wild-caught females. This is in contrast to striped trumpeter (Morehead et al. 1998) and some other species treated shortly after capture from the wild which exhibited no decline in egg viability after implantation, suggesting that they adapted readily to handling and stripping during confinement after hormonal treatment. Further, if implantation was delayed delay for five days after capture, this resulted in a poor and unsatisfactory response in terms of the proportion of females ovulating and the number of eggs collected from spawning females. This appears to be different to the situation in striped trumpeter where animals responded equally well even when hormonal treatment began up to six days from first capture. Unlike striped trumpeter, where development in maturing oocytes was arrested for the six days before LHRHa treatment and then continued to develop normally after treatment, banded morwong oocytes did not appear to continue normal development after a prolonged arrest. Also unlike striped trumpeter, banded morwong caught during the spawning season did not readily eat or adapt to captivity. Such adverse influences may be the principal cause of the diminishing responsiveness with the increasing delay in LHRHa treatment (Pankhurst 1998). It is therefore imperative that treatment commences immediately after capture to maximise the potential for egg production in all females.

The time of egg collection after hormonal treatment is important. Any delay, which causes aging, then reduces fertilisation and larval hatch. In this study, banded morwong females were hand stripped daily and peak egg production occurred two days after implantation with LHRHa pellets. However, some animals examined at $45 \mathrm{~h}$ could not be stripped whereas at $48 \mathrm{~h}$ they could. Our other studies (not published) suggested that with as little as $1 \mathrm{C}$ increase or decrease in water temperature, animals could be stripped $3 \mathrm{~h}$ earlier or later, respectively. This indicates that the time of collection needs to be determined precisely with regard to holding conditions to optimise egg quality. A delay in collection may have been partly responsible for the poor egg quality on Day 4 after implantation in the second experiment. Other indicators of egg quality include oil droplet parameters (Bromage 1995). However, in this study, the proportion of eggs with single oil droplets was mostly $>90 \%$ and there was no indication that eggs with poor fertilisation had a higher proportion of multiple oil droplets.

For females implanted immediately and collected on Day 2, embryonic mortality was low on the first day during incubation compared to the high mortality of eggs collected on Day 4. The mortality rates were similar thereafter indicating that poor egg quality is reflected in high mortality early during incubation. A similar phenomenon was observed previously in striped trumpeter when poorer quality (with frozen-thawed) semen resulted in early death of 
inseminated eggs (i.e. within 2 days of the normally 6-day embryonic development) compared to the use of fresh semen (Ritar 1999). Here, the overall proportion of eggs hatching was low where poor eggs were used, possibly because they did not fertilise after insemination or early embryonic development was abnormal. The small-scale method of egg incubation in vials appeared effective in testing the quality of eggs, where frequent ( $\geq$ twice daily) exchanges with filtered water during development maintained satisfactory water quality, minimising bacterial abundance and preventing embryonic mortality due to disease.

For eggs collected from banded morwong females treated with LHRHa implants, embryonic and larval development appeared normal after insemination and incubation at 17$18 \mathrm{C}$. This is some 3-4 C higher than the ambient temperature at which females naturally ovulate but there were no apparent abnormalities during development. The higher temperatures may equate to those experienced naturally in the wild by the pelagic eggs and embryos close in-shore in shallow, calm waters of the normal spawning areas.

In this first study of banded morwong larvae and post-larve, the growth rates may be regarded as relatively slow, with animals reaching $22 \mathrm{~mm}$ (standard length) at 100 days after hatch. However, with improved culture conditions, this would be expected to increase markedly. For example, the growth rate of striped trumpeter after hatch to 100 days improved by $40 \%$ during the last seven years as a result of considerable advances in hatchery procedures following research on abiotic (water temperature, chemistry, turbidity, turbulence) and biotic (feeding regime, larval density, behaviour) factors (Battaglene and Cobcroft, in press). Typical bottlenecks to larval development include overcoming problems to swim bladder inflation, diseases and the need for specific diets. It is likely that many of the improvements in striped trumpeter culture could readily be adopted and modified for banded morwong to increase larval survival and growth.

In summary, this study showed that banded morwong females caught from the wild during the autumn spawning season can be effectively induced and synchronized to ovulate, producing reliably large quantities of viable eggs. The LHRHa treatment induced at least two successive spawns starting two days after implantation of the slow-release cholesterol implants and continued at two-day intervals. However, delaying implantation reduced the proportion of animals ovulating, their average production of eggs and the viability of eggs compared to animals treated immediately after capture. When eggs produced by this hormonal induction were used for hatchery rearing, the larvae could be grown to post-larve, thus providing the opportunity in future to assess their suitability for commercial aquaculture in Australia.

\section{Acknowledgements}

We thank Mark Cuthbertson for supplying wild broodstock. Polly Hilder, Lance Searle, Steve Nel and staff of the Aquaculture Development Program are thanked for their assistance. Dr Randy Rose provided supervision of T. Pribadi. Dr Stephen Battaglene provided helpful comments on the manuscript. 


\section{Literature Cited}

Battaglene, S.C. and J.M. Cobcroft. (in review). Advances in the culture of striped trumpeter larvae: a review. Aquaculture

Bromage, N. 1995. Broodstock management and seed quality - general considerations. Pages 1-24 in N.R. Bromage and R.J. Roberts, editors. Broodstock Management and Egg and Larval Quality. Blackwell Science, Oxford, U.K..

Bruce, B. 1989. Cheilodactylidae: Morwongs. Pages 150-153 in J.M. Leis and T. Trnski, editors. The Larvae of Indo-Pacific Shorefishes. New South Wales University Press, Sydney, Australia.

Bruce, B. 1998. Cheilodactylidae: Morwongs. Pages 210-213 in F.J. Neira, A.G. Miskiewicz and T. Trnski, editors. Larvae of Temperate Australian Fishes: Laboratory Guide for Larval Fish Identification. University of Western Auastralia Press, Nedlands, Australia.

Clearwater, S.J. and N.W. Pankhurst. 1997. The response to capture and confinement stress of plasma cortisol, plasma sex steroids and vitellogenic oocytes in the marine teleost, red gurnard. Journal of Fish Biology 50:429-441.

Crim, L.W., R.E. Peter, and G. Van Der Kraak. 1987. The use of LHRH analogs in aquaculture. Pages 489-498 in B.C. Vickery and J.J., Jr. Nestor, editors. LHRH and its Analogs: Contraceptive and Therapeutic Application, Part II. MTP Press, Lancaster, U.K..

Jordan, A. 1994. Species profile - banded morwong. Fishing Today 7(4):35-37.

Kuiter, R.H. 1993. Coastal fishes of South-Eastern Australia. University of Hawai'i Press, U.S.A.

Last, P.R., E.O.G. Scott, and F.H. Talbot. 1983. Fishes of Tasmania. Tasmanian Fisheries Development Authority, Hobart, Tasmania, Australia.

Lee, C.-S., C.S. Tamaru and C.D. Kelley. 1986. Technique for making chronic-release LHRHa and $17 \alpha$-methyl-testosterone pellets for intramuscular implantation in fishes. Aquaculture 59:161-168.

Leum, L.L. and J.H. Choat 1980. Density and distribution patterns of the temperate marine fish Cheilodactylus spectabilis (Cheilodactylidae) in a reef environment. Marine Biology 57:327-337.

McCormick, M.I. 1989. Reproductive ecology of the temperate reef fish Cheilodactylus spectabilis (Pisces: Cheilodactylidae). Marine Ecology Progress Series 55:113-120.

Morehead, D. T., N.W. Pankhurst and A.J. Ritar. 1998. Effect of treatment with LHRH analogue on oocyte maturation, plasma sex steroid levels and egg production in female striped trumpeter Latris lineata (Latrididae). Aquaculture 169:315-331.

Murphy, R.J., and Lyle, J.M. 1999. Impact of gillnet fishing on inshore temperate reef fishes, with particular reference to banded morwong. University of Tasmania, Marine Research Laboratories, Tasmanian Aquaculture and Fisheries Institute, Report for the Fisheries Research Development Corporation, Final Report 95/145. 136 pp. http://www.utas.edu.au/tafi/PDF_files/GillnetFRDC-finalreport.pdf.

Mylonas, C.C. and Y. Zohar. 2001. Use of GnRHa-delivery systems for the control of reproduction in fish. Reviews in Fish Biology and Fisheries 10:463-491.

Pankhurst, N.W. 1998. Reproduction. Pages 1-26 in Black, K.D., Pickering, A.D., editors. Biology of Farmed Fish. Sheffield Academic Press, Sheffield, U.K..

Ritar, A.J. 1999. Artificial insemination with cryopreserved semen from striped trumpeter (Latris lineata). Aquaculture 180:177-187. 
Roberts, C.D. 1995. A review of postlarval paperfish stage and its contribution to Cheilodactylid systematics. International Larval Fish Conference, Sydney, Australia.

Searle, L.D. and W. Zacharin. 1994. Aquaculture research needs in Tasmania: species priorities and research strategies for the development of finfish, invertebrate and seaweed industries. Internal Report. Department of Primary Industry and Fisheries, Tasmania, Australia.

Steel, R.G.D. and J.H. Torrie. 1960. Principles and Procedures of Statistics. McGraw-Hill, New York, U.S.A.

Trotter, A.J., P.M. Pankhurst and S.C. Battaglene. 2004. Morphological development of the swim bladder in hatchery-reared striped trumpeter Latris lineata. Journal of Applied Ichthyology 20:395-401.

Wolf, B. 1998. Update on juvenile banded morwong in Tasmania. Fishing Today 11(4):30-31.

Woods, L.C. and C.V. Sullivan. 1993. Reproduction of striped bass, Morone saxatilis (Walbaum), broodstock: monitoring maturation and hormonal induction of spawning. Aquaculture and Fisheries Management 24:211-222.

Ziegler, P.E., Lyle, J., Haddon, M., Burch, P. 2005. Developing assessments and performance indicators for a small-scale temperate reef fish fishery. In: Kruse, G.H., Gallucci, V.F., Hay, D.E., Perry, R.I., Peterman, R.M., Shirley, T.C., Spencer, P.D., Wilson, B., and Woodby, D. (eds.). Assessment and management of new and developed fisheries in data-limited situations. Alaska Sea Grants College Program, University of Alaska Fairbanks, Alaska, 195-211.

Zohar, Y. 1986. Gonadotropin releasing hormone in spawning induction in teleosts: basic and applied consideration. Pages 47-61 in Zohar, Y. and Breton, B., editors. Reproduction in Fish - Basic and Applied Aspects in Endocrinology and Genetics. INRA, Paris, France. 
Table 1. Egg volume, fertilisation rate, proportion of eggs with single (rather than multiple) oil droplet, embryonic mortality (dead, sinking eggs) and larval hatch of eggs collected and inseminated 2 or 4 days after banded morwong females were implanted with LHRHa slowrelease pellets within $24 \mathrm{~h}$ of capture (Experiment 2 ).

\begin{tabular}{|c|c|c|c|c|c|c|c|c|c|}
\hline & \multirow{2}{*}{$\begin{array}{l}\text { Number } \\
\text { females } \\
\text { stripped }\end{array}$} & \multirow{2}{*}{$\begin{array}{l}\text { Egg } \\
\text { volume } \\
(\mathrm{ml})\end{array}$} & \multirow{2}{*}{$\begin{array}{l}\text { \% eggs } \\
\text { fertilised }\end{array}$} & \multirow{2}{*}{$\begin{array}{l}\text { \% single } \\
\text { oil droplet }\end{array}$} & \multicolumn{3}{|c|}{ \% dead (sinking) eggs: } & \multirow{2}{*}{$\begin{array}{l}\% \text { larval } \\
\text { hatch } \\
(\sim 67 \mathrm{~h})^{\mathrm{a}}\end{array}$} & \multirow{2}{*}{$\begin{array}{l}\text { Total no } \\
\text { of eggs } \\
\& \text { larvae }\end{array}$} \\
\hline & & & & & $1^{\text {st }}$ day & $2^{\text {nd }}$ day & $>2^{\text {nd }}$ day & & \\
\hline \multicolumn{10}{|c|}{ Stripped on Day 2 after implanation } \\
\hline $\begin{array}{l}\text { Mean } \\
\text { (s.e.m.) }\end{array}$ & 18 & $\begin{array}{l}135.3 \\
(15.3)\end{array}$ & $\begin{array}{l}79.2 \\
(7.6)\end{array}$ & $\begin{array}{l}88.9 \\
(5.6)\end{array}$ & $\begin{array}{c}1.7 \\
(0.9)\end{array}$ & $\begin{array}{l}34.7 \\
(8.2)\end{array}$ & $\begin{array}{l}5.8 \\
(2.5)\end{array}$ & $\begin{array}{l}57.8 \\
(8.6)\end{array}$ & $\begin{array}{l}194.3 \\
(3.9)\end{array}$ \\
\hline \multicolumn{10}{|c|}{ Stripped on Day 4 after implanation } \\
\hline $\begin{array}{l}\text { Mean } \\
\text { (s.e.m.) }\end{array}$ & 17 & $\begin{array}{c}107.1 \\
(9.8)\end{array}$ & $\begin{array}{l}23.1 \\
(7.4)\end{array}$ & $\begin{array}{l}90.8 \\
(4.3)\end{array}$ & $\begin{array}{l}51.4 \\
(7.0)\end{array}$ & $\begin{array}{l}29.1 \\
(3.4)\end{array}$ & $\begin{array}{c}4.4 \\
(1.5)\end{array}$ & $\begin{array}{l}15.0 \\
(6.1)\end{array}$ & $\begin{array}{l}189.1 \\
(8.9)\end{array}$ \\
\hline Significa & $c e^{b}$ & * & $* *$ & N.S. & ** & N.S. & N.S. & ** & N.S. \\
\hline
\end{tabular}

a Time to hatch at $17 \mathrm{C}$ was approximately $67 \mathrm{~h}$ (47.5 degree-days) after insemination.

$\mathrm{b}$ significance determined between banded morwong eggs collected and inseminated 2 or 4 days after LHRHa implanation ( $* \mathrm{P}<0.05, * * \mathrm{P}<0.01$, N.S. not significant). 


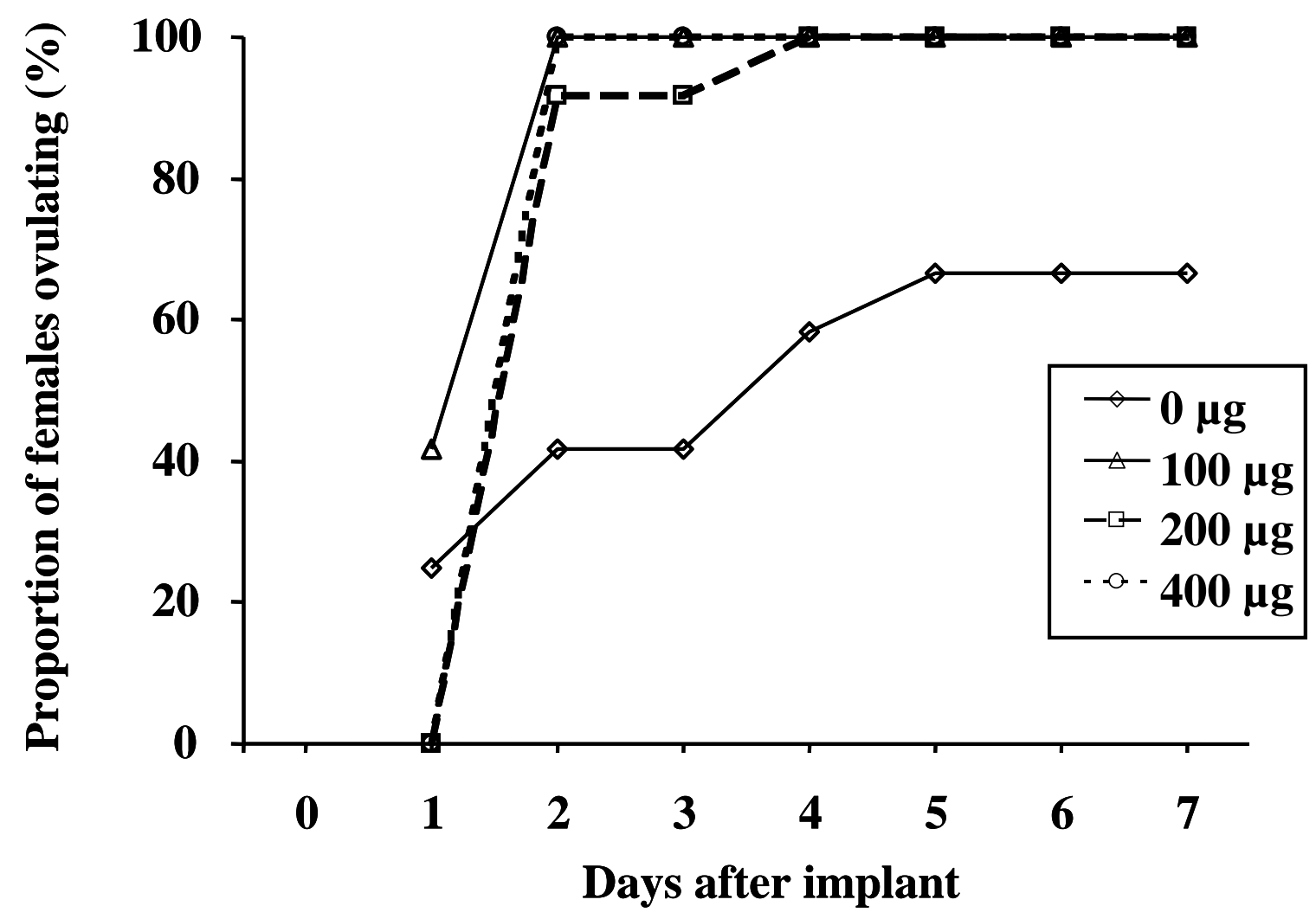

Figure 1. Cumulative proportion of banded morwong females first ovulating after treatment with slow-release implants containing 0, 100, 200 or $400 \mu \mathrm{g} \mathrm{LHRHa/kg} \mathrm{body} \mathrm{weight}$ (Experiment 1). 


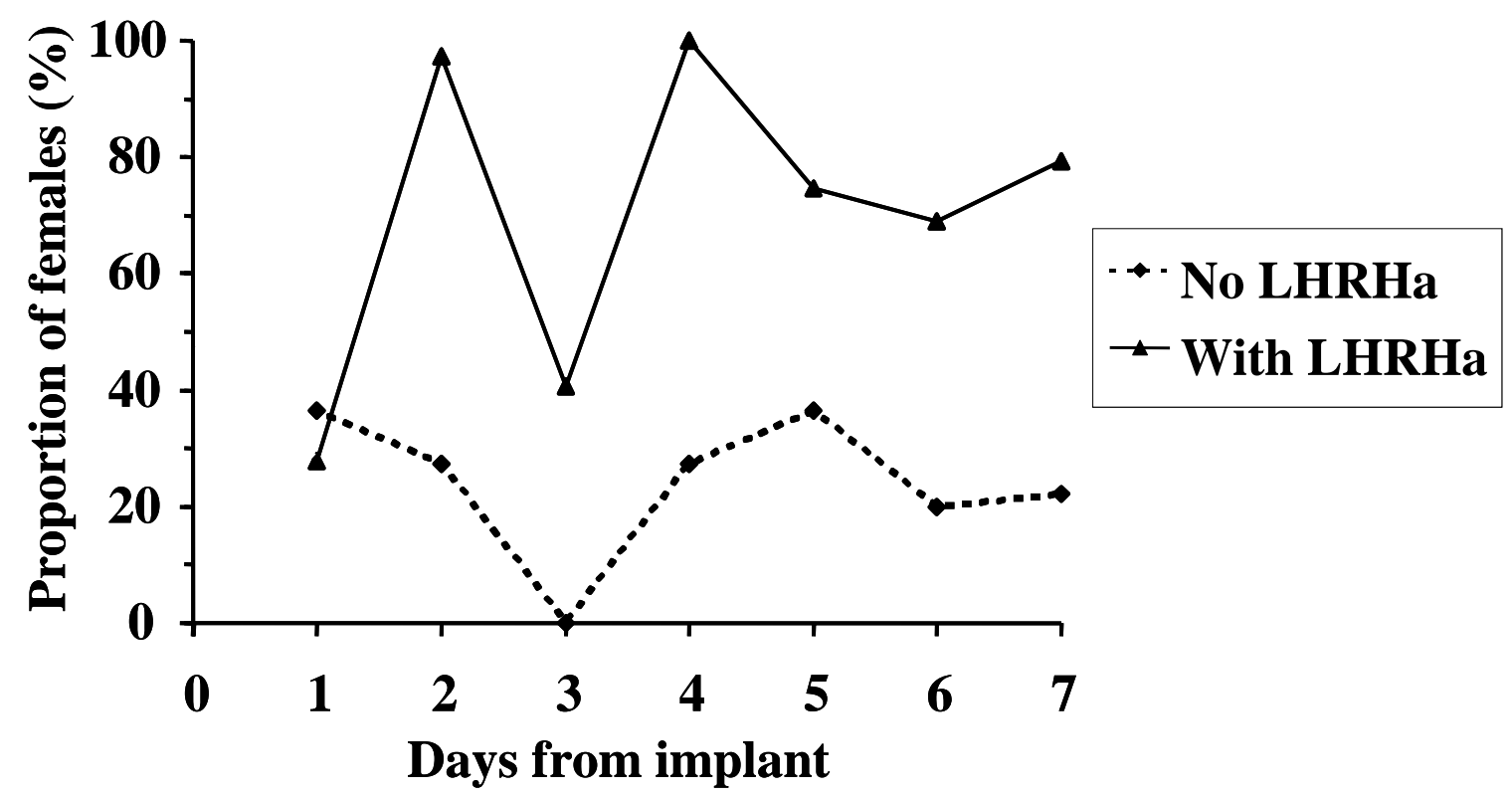

Figure 2. Proportion of banded morwong females which could be stripped on each day following treatment with slow-release implants containing LHRHa (pooled for treatment with 100, 200 and $400 \mu \mathrm{g}$ LHRHa/kg body weight) or no LHRHa (Experiment 1). 


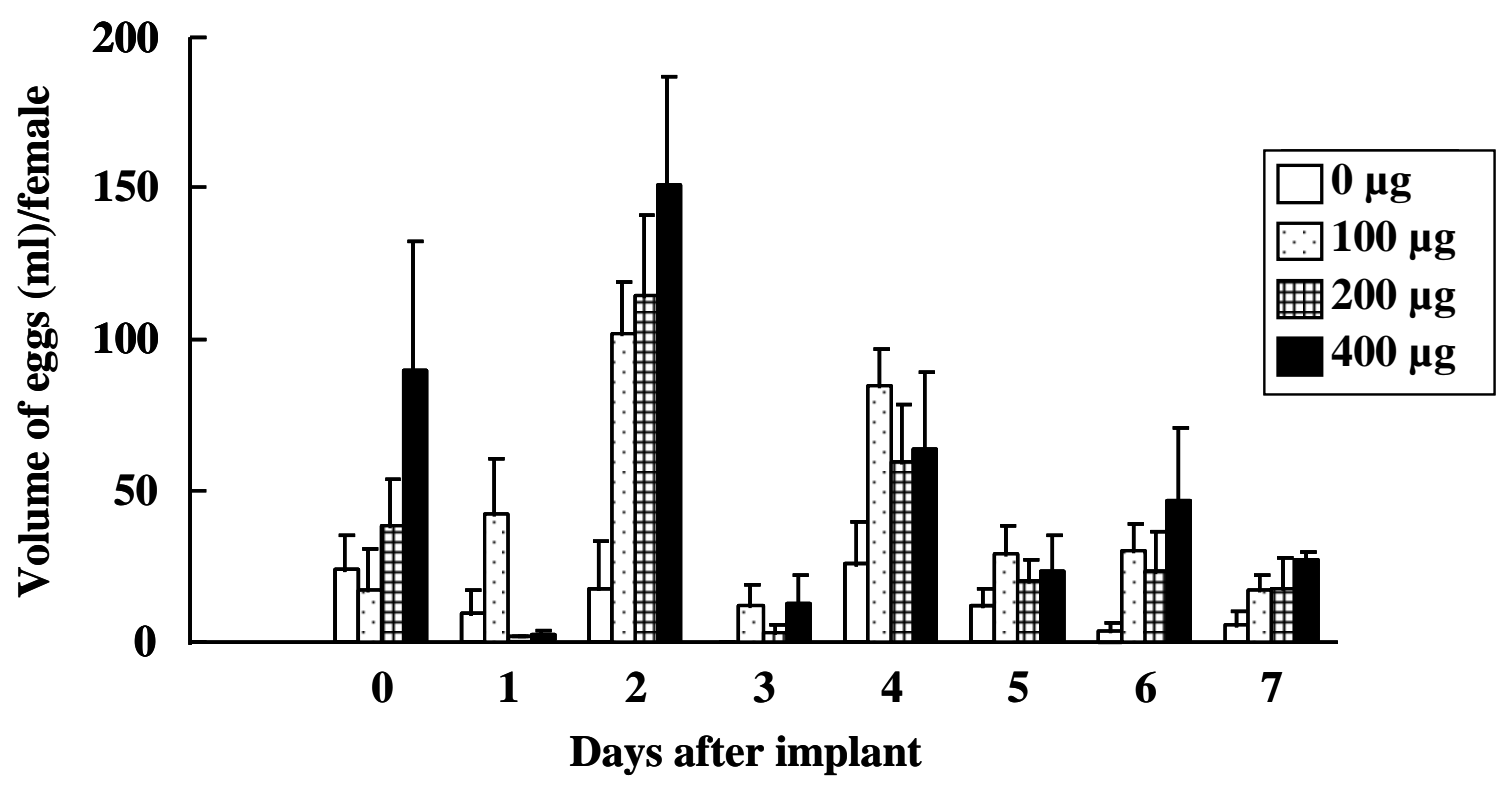

Figure 3. Volume of eggs (mean \pm sem) collected from banded morwong females that ovulated on each day following treatment with slow-release implants containing 0,100, 200 or $400 \mu \mathrm{g}$ LHRHa/kg body weight (Experiment 1). 


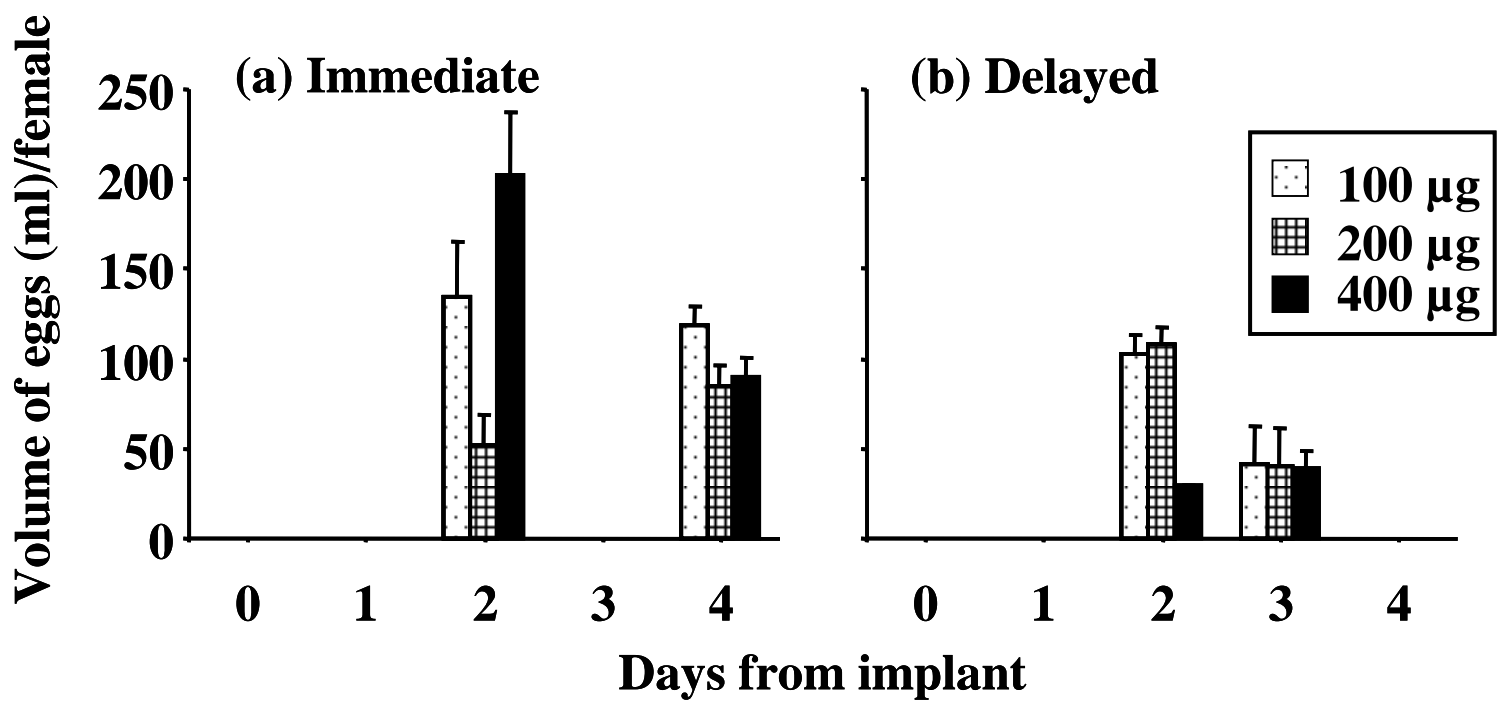

Figure 4. Volume of eggs (mean \pm sem) collected from banded morwong females that ovulated on each day following treatment with slow-release implants containing 100, 200 or $400 \mu \mathrm{g}$ LHRHa/kg body weight either (a) immediately (within $24 \mathrm{~h}$ of capture) or (b) delayed by 5 days after capture (Experiment 2). 


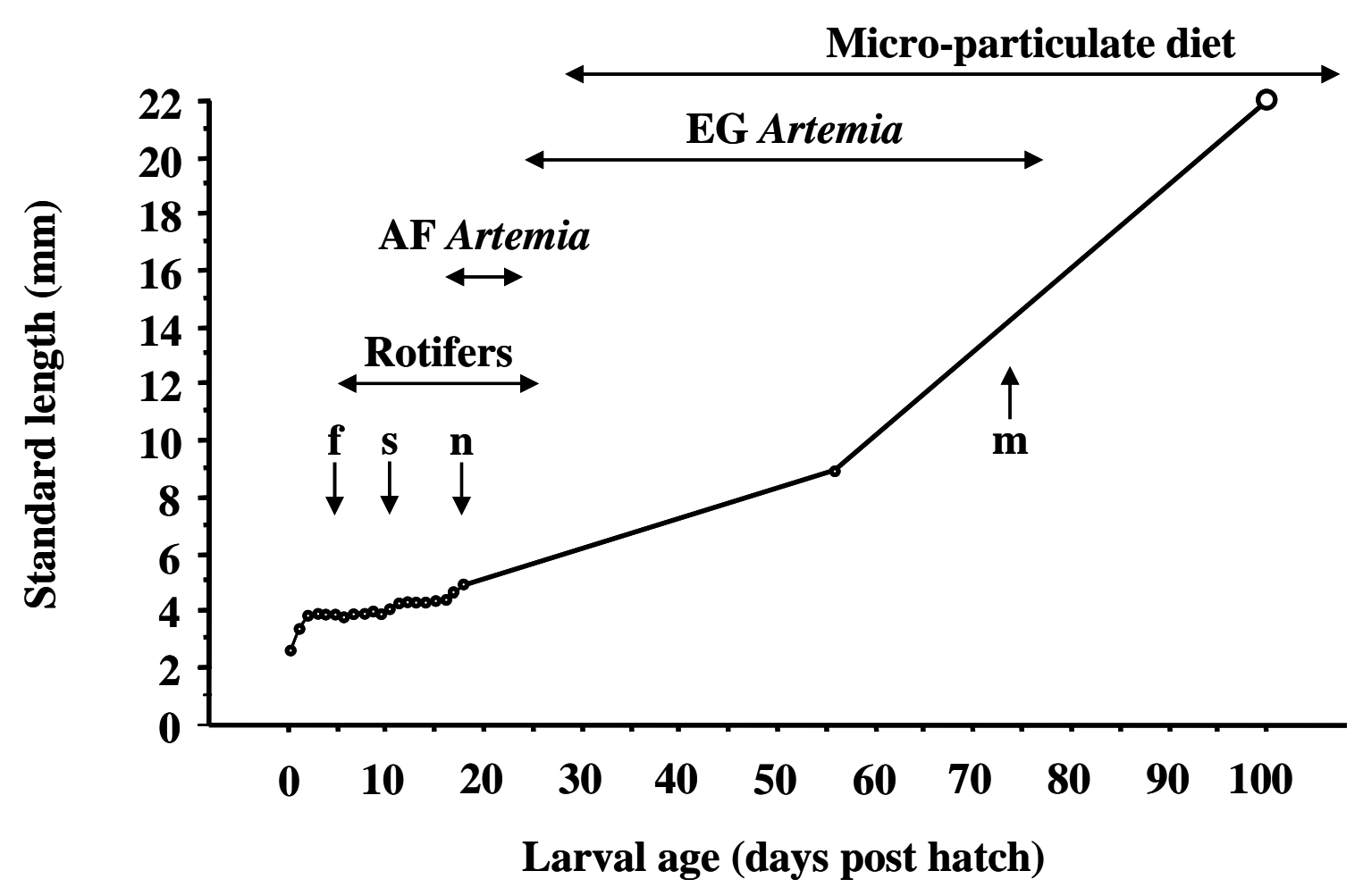

Figure 5. Growth (standard length) of banded morwong larvae and post-larvae during culture at $18 \mathrm{C}$ and their feeding regime. Arrows indicate critical points during development: $\mathrm{f}$, first feeding; s, swim bladder inflation; $n$, notochord flexion; $\mathrm{m}$, metamorphosis to post-larval paperfish stage. Horizontal bars indicate the period during which animals were fed enriched rotifers, AF Artemia nauplii, EG Artemia metanauplii and juveniles, and a micro-particulate (Kyowa) diet. 